УДК $398+82$ I.52I+82I.I6I.I ББК 82.3 (5Япо) + $83.3(2 \mathrm{Poc}=\mathrm{Pyc})$
«КОДЗИКИ» И ФОЛЬКЛОРИСТИЧЕСКИЕ РАЗЫСКАНИЯ А.А. ВАНОВСКОГО ПРИ ИЗУЧЕНИИ ГЕНЕЗИСА МИФОЛОГИЧЕСКИХ СУЩНОСТЕЙ В АРХАИЧЕСКИХ МИФАХ ТВОРЕНИЯ ДРЕВНЕЙ ЯПОНИИ

\author{
(C) 2020 г. А.Л. Налепин \\ Институт мировой литературы \\ им. А.М. Горького Российской академии наук, \\ Москва, Россия \\ Дата поступления статьи: I3 апреля 2019 г. \\ Дата публикации: 25 июня 2020 г. \\ DOI: I0.22455/2500-4247-2020-5-2-390-4II
}

Аннотация: Настоящая публикация продолжает исследование фольклористических штудий Александра Вановского в области изучения фольклорной культуры Древней Японии, начатое в 2018 г. в статье «Японский фольклор в работах А.А. Вановского и их значение для русско-японского культурного трансфера», опубликованной в журнале «Studia Literarum» [7, с. 276-297], вводит в научный и культурный оборот работы оригинального философа XX столетия Александра Вановского, профессионального русского революционера, ставшего в японской эмиграции под влиянием произведений Шекспира самобытным религиозным мыслителем и интересным литературоведом, уделившим много внимания развитию русско-японской компаративистики. Публикация обогащает японскую, европейскую и русскую фольклористику, предлагая новые смыслы «прочтения» памятников эпоса древней Японии. Изучение творческого наследия Александра Вановского поможет найти и определить гармонический синтез философии и фольклора, что, несомненно, обогатит как философскую мысль (в частности, философскую теорию познания), так и отечественную фольклористику.

Ключевые слова: А.А. Вановский, Россия и Япония, русская эмиграция, Кодзики, русская и японская фольклорная культура, вулканы.

Информация об авторе: Алексей Леонидович Налепин - доктор филологических наук, ведущий научный сотрудник, Институт мировой литературы им. А.М. Горького Российской академии наук, ул. Поварская, д. 25 а, І2Іо69 г. Москва, Россия.

E-mail:a_nalepin@mail.ru

Для цитирования: Налепин А.Л. «Кодзики» и фольклористические разыскания А.А. Вановского при изучении генезиса мифологических сущностей в архаических мифах творения Древней Японии // Studia Litterarum. 2020. T. 5 , № 2. C. 390-4II. DOI: IO.22455/2500-4247-2020-5-2-390-4II 


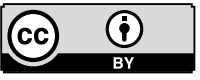

This is an open access article distributed under the Creative Commons Attribution 4.0 International (CC BY 4.0)

\section{"KOJIKI" AND A.A. VANOVSKY ON THE GENESIS OF MYTHOLOGICAL ENTITIES IN THE ARCHAIC MYTHS OF THE OF ANCIENT JAPAN}

(C) 2020. A.L. Nalepin

A.M. Gorky Institute of World Literature

of the Russian Academy of Sciences, Moscow, Russia

Received: April I3, 2019

Date of publication: June 25, 2020

Abstract: This article bears on the previous research of folkloristic works by Alexander Vanovsky in the field of Japan folklore studies. The research was initiated in 2018 by the article "Japanese Folklore in the Works of A.A. Vanovsky and Their Importance for the Russian-Japanese Cultural Transfer" (Studia Litterarum [7, p. 276-297]). It introduces works by an outstanding $2 \mathrm{O}^{\text {th }}$ century philosopher Alexander Vanovsky, a professional Russian revolutionary who became an original religious thinker and an interesting literary critic in Japanese emigration. Vanovsky paid much attention to the development of Russian-Japanese comparative studies. This article enriches Japanese, European, and Russian folklore studies, by offering new interpretation of the ancient Japan epic. The study of Vanovsky's heritage allows us to establish a harmonious synthesis of folklore studies and philosophy that is beneficial for both philosophical thought (especially the cognition theory) and the study of folklore in Russia.

Keywords: Vanovsky, Russia and Japan, Russian emigration, Kojiki, Russian and Japanese folk culture, volcanoes.

Information about the author: Alexey L. Nalepin, DSc in Philology, Leading Research Fellow, A.M. Gorky Institute of World Literature of the Russian Academy of Sciences. Povarskaya 25 a, I21069 Moscow, Russia.

E-mail:a_nalepin@mail.ru

For citation: Nalepin A.L. "Kojiki" and A.A. Vanovsky on the Genesis of Mythological Entities in the Archaic Myths of the Ancient Japan. Studia Litterarum, 2020, vol. 5, no 2, pp. 390-4II. (In Russ.) DOI: IO.22455/2500-4247-2020-5-2-390-4II 
Настоящая публикация продолжает исследование фольклористических разысканий А.А. Вановского в области изучения фольклорной культуры Древней Японии, начатое в 2018 г. в статье «Японский фольклор в работах А.А. Вановского и их значение для русско-японского культурного трансфера», опубликованной в журнале «Studia Litterarum» [7, с. 276-297].

Следует особо оговорить, что весьма специфические взгляды Александра Вановского, волею судеб оказавшегося в Японии (экзотической для него стране), не знавшего ни языка этой страны, ни ее культуры, ни ее истории, представляли собой наивную попытку пытливого русского эмигранта хотя бы каким-то образом попытаться понять и вписаться в японскую культуру, понять ментальность людей, живущих в Японии, в той стране, где ему, Александру Алексеевичу Вановскому, предстояло жить и умереть. Поэтому не имеют никакого практического смысла попытки соотнесения взглядов Вановского с постулатами японистики как серьезной эволюционирующей науки. Японистика Вановского была наукой особого рода. Она, конечно же, не имела никакого представления ни о знаменитой поливановской системе русской фонетической транскрипции японских слов, разработанной и предложенной в I9I7 г. выдающимся отечественным лингвистом и востоковедом Евгением Дмитриевичем Поливановым (I89I-I938), ни о классических переводах на русский язык «Кодзики», опубликованных в 2000 г. Е.М. Пинус, Д.М. Ермаковой и А.Н. Мещеряковым, ни о классических трудах по японской мифологии академика Н.И. Конрада и многих других.

Объективно говоря, «Японистика по Вановскому» носила утилитарный, во многих отношениях даже «доморощенный» характер, отразила его наивные представления о Японии столетней давности. Для человека, не 
обладавшего ни исторической, ни филологической подготовкой, заставившего себя не спасовать перед громадой древней японской истории, культуры и японского языка, именно такой «дилетантский» метод погружения в незнакомый экзотический материал представлялся единственно возможным. Именно по этой причине в настоящем исследовании особо не оговаривается, что в приводимых цитатах сохраняется оригинальное написание, характерное для начала XX столетия, т. е. времени, когда Вановский стал заниматься своими «японскими» исследованиями. Так, например, приводимое Вановским имя героя УРАШИМА сегодня, согласно общепринятой транскрипции Е.Д. Поливанова, должно звучать как УРАСИМА.

До недавнего времени имя Александра Алексеевича Вановского (I874 Тула - І967 Токио), этого оригинального русского ученого-эмигранта, тонкого и своеобразного философа, литературоведа и общественного деятеля, было известно лишь узкому кругу специалистов, главным образом, историков, занимающихся историей революционного движения в России.

Между тем Вановский является самобытным ученым, многого достигшим на поприще разных гуманитарных дисциплин - фольклористики, этнологии, философии и литературоведения. Большой интерес вызывают судьба и деятельность этого человека - не только своеобразного философа $\mathrm{XX}$ столетия, но и одного из основателей РСДРП, делегатом I съезда которого он являлся, профессионального революционера-боевика, ставшего в японской эмиграции под влиянием произведений Шекспира оригинальным религиозным мыслителем, продолжателя традиций философии Серебряного века и, наконец, интересного литературоведа, уделившего много внимания становлению и развитию русско-японской компаративистики.

Пройдя сложный, мучительный путь духовного Возрождения, путь от революционера-боевика до самобытного мыслителя мирового масштаба, Вановский после революции г905 г. вышел из РСДРП и принял христианство или, как он сам выразился в частном письме, «через Шекспира перешел от Маркса к Христу». В г19 г. он заболел нервным расстройством и переехал на лечение в Японию, где прожил почти 50 лет до своей кончины в 1967 г. Он преподавал русскую литературу в Токио в Университете Васэда, изучал японские фольклорные памятники с точки зрения вулканологии, публиковал материалы о своей революционной биографии, размышляя о том, почему гуманные идеи революционеров всегда приводят к трагедии. Ванов- 
ский считал, что возрождение России возможно только через обновленное христианство [9; го].

Своеобразным оказалось изучение Вановским феномена японской фольклорной культуры через призму японской мифологической системы «Кодзики». Вановский был первым ученым, кто текстуально сравнил языческие тексты японской «Кодзики» («Записи о деяниях древности») с каноническим текстом христианской Библии. Исследование фольклорной составляющей его философского наследия доказывает, что фольклорная культура России и Японии, будучи живой традицией, во многом определяла пути развития и японской, и русской цивилизации, а также смыслы их национальной ментальности. Важную роль в этом играл фольклор и, конечно же, фольклористика, как филологическая, так и философская, изучающая мировоззренческие доминанты и концепты народно-поэтического творчества. Творческое наследие Александра Вановского являет собой гармонический синтез философии и фольклора, что в значительной мере обогащает как философскую мысль, в частности, философскую теорию познания, так и фольклористику.

Важным этапом в изучении творческого наследия Александра Вановского стала опубликованная в 1995 г. в бюллетене университета Хоккайдо «Acta Slavica Iaponica» [4, c. I49-I66] работа известного исследователя японской культуры, литературоведа и искусствоведа Ирины Петровны Кожевниковой о жизни и трудах Вановского. В этой работе представлены стенографические записи бесед исследовательницы с Вановским, что представляет особый интерес [4, с. I49-I66].

Переехав в Японию и чувствуя определенный социально-культурный дискомфорт, вызванный полным незнанием японского языка, японской истории и культуры, не понимая поэтому вообще японского менталитета, русский эмигрант Александр Алексеевич Вановский приступает к изучению и осмыслению японской мифологии. В г92г г. в Харбине выходит его работа «В стране богов. Мысли об Урашиме - герое древне-японской легенды». Пересказывая эту легенду, Вановский дает свое философское толкование этого памятника японской фольклорной культуры: человек, совершивший паломничество в «страну бессмертия», вернувшись в прежнюю жизнь, не может оставаться обычным человеком. «Своими переживаниями в стране богов, - пересказывала автора И.П. Кожевникова, - Урашима создал себе 
свое будущее, предопределил свой земной путь. Он бессознательно сплел сети своей кармы и сам поймал себя в них» [4, с. I53].

В определенной степени Вановский соотносил эту древнюю японскую легенду с фактами собственной биографии, со своей собственной судьбой, связанной с поиском «сетей своей кармы», в частности, с тем его мистическим видением-прозрением, которое во многом и предопределило его японский исход, его японскую судьбу. И.П. Кожевникова пересказала для нас эту волшебную японскую сказку, которая так взволновала и пленила Александра Вановского:

Ему приснился вещий сон, по его словам - «замечательное сновидение», которое он назвал «космическим». Будто он находится в большом городе, а вверху блистает грандиозный фейерверк небесных огней, похожих на извержение вулкана. По небу двигаются сияющие планеты, оставляя сверкающие следы. С высоты небес медленно спускается бесконечная вереница людей в пламенных одеждах, их черные волосы и желтоватые лица придают им восточный вид. Вокруг одной из планет вьются огненные вихри, и на одно из мгновений она показалась Вановскому раскрытой книгой, листы которой треплет ветер. На черном, как уголь, небе остаются сверкающие следы от движущихся светил, которые, переплетаясь, складываются в сложный узор, похожий на огненные письмена. Склонный к предчувствиям и предзнаменованиям, Вановский расшифровал этот сон так: ему суждено будет попасть в страну с действующими вулканами и большими городами, где живут люди с желтой кожей, т. е. в Японию. Огненные письмена он понял как указание на таинственную книгу, которую ему суждено будет расшифровать, а в планете, похожей на книгу с трепещущими листами, - намек на «Апокалипсис», которым он в то время начал интересоваться [4, с. 150-I5I].

Видимо, И.П. Кожевникова записала поздний вариант этого пророческого видения, которое Вановский рассказывал уже на склоне лет. Друзья Александра Вановского вспоминали, что слышали от него и иной рассказ, в котором говорилось, что он увидел во сне некий похожий на лотос прекрасный цветок, который, распустившись, явил ему прекрасную женщину-птицу, обернувшуюся красавицей-японкой, которая взмахами крыльев-рук и позвала его к себе. Так Александр Вановский мистически объяснял себе са- 
мому и окружающим причину того, как он оказался в Японии. Впрочем, не следует забывать и того, что причиной переезда А.А. Вановского в Японию была необходимость экстренного лечения тяжелого психического недуга.

Александр Вановский вообще любил всякого рода мистификации, чему немало способствовали его многолетний опыт революционной конспиративной работы и богатое воображение, усугубленное душевным заболеванием. Александра Вановского с полным основанием можно считать «королем мистификации». Его мистификации в буквальном смысле «спасали» его от американских оккупационных чиновников, которых вокруг него всегда было более чем достаточно. Их интерес к Вановскому был вызван его революционным прошлым в России (в частности, тем, что он был делегатом Первого съезда РСДРП), а также его близким знакомством с В.И. Лениным и другими деятелями революционного движения и громадным опытом профессионального революционера-боевика (не только как практика, но и крупного теоретика революционного террора). Как правило, мистификации Вановского «крутились» вокруг его якобы постоянных контактов с «зелеными человечками». Рассказывают, что на встречу с ними он постоянно приглашал своих американских кураторов, но, когда последние приходили к Александру Алексеевичу, тот с сожалением разводил руками и говорил: «Только что, перед вашим приходом, они улетели». В эту наивную игру-мистификацию он продолжал играть до конца своих дней и даже опубликовал в Нью-Йорке І3 апреля 1952 г. в газете «Новое русское слово» статью под названием «Марсиане в квадрате».

Вановский рассматривал фольклорный памятник об урашиме в первую очередь как исторический источник, почти наощупь, как может поступать только пытливый иностранец, что называется «Devisu», совершая поездку по фольклорно-историческим следам героя этой легенды. Он побывал на могиле Урашимы с памятником в виде черепахи, которую поймал герой легенды. Посетил древний храм, воздвигнутый в честь Урашимы, где хранились священные реликвии: ларец морской царевны, волшебная удочка, которой герой легенды поймал черепаху, и палец героя. Он был русским эмигрантом, и «открытие» этого текста на вербальном уровне случилось много позже. Для Александра Вановского, не владевшего японским языком, смысл этого фольклорного памятника раскрывался не в словах, а в многочисленных сохранившихся деталях исчезнувшей фольклорной эпохи. Такое 
«тактильное», почти на осязательном уровне осмысление фольклорного произведения удивительным образом совпало с «пророческим видением», которое во многом предопределило необыкновенную японскую судьбу этого русского человека. Это и другие подобные историко-фольклорные путешествия стали «фирменным стилем» неофита Вановского, открывая ему дверь к познанию Японии.

Аналогичные методы исследования памятников фольклора, включая археологические методы, предлагала использовать, например, молодая американская фольклористика. В ряду других исследователей, кто активно использовал фольклор в качестве исторических источников, следует назвать известного американского антрополога, писателя и археолога Джесси Уолтера Фьюкеса (I850-I930), который в начале XX столетия ратовал именно за такое комплексное изучение фольклора США, отстаивая тезис, что именно фольклор в состоянии разъяснить как историю, так и археологию. Исследуя руины, сохранившиеся вокруг некоторых индейских деревень, Фьюкес одновременно собирал и произведения фольклора, полагая, что «легенды и мифы индейцев являлись важным руководством для воссоздания истории племен. Другими словами, фольклорная традиция содержала в себе исторический факт» [13, с. 32]. Наиболее важной для становления американской фольклористики была теоретическая установка Фьюкеса на то, что любое изучение археологических памятников неизбежно влечет за собой изучение современного фольклора (главным образом легенд и мифов об этих археологических памятниках). Только таким образом, утверждал американский археолог, возможно понять «нравы и обычаи тех людей, которые некогда обитали в них (т. е. в том, что сейчас является руинами. - А.Н.)» [12, с. 578].

Мировоззрение и морально-эстетические вкусы Александра Вановского - будущего исследователя мифологии «Кодзики» (древних японских мифов творения) - формировались под влиянием в первую очередь семьи. Сестра Зина «знакомила меня с начатками религии. Она рассказывала мне о Боге, о прекрасных ангелах, живущих в райских садах на небе, а также передавала своими словами разные трогательные эпизоды из жизни Спасителя. В общем, она напирала на светлую сторону религии, тогда как няня, наоборот, больше говорила о чертях, ведьмах, адских муках и Страшном суде. Солнечная и мрачная стороны религии сливались в моей душе в одно морально- 
эстетическое мироощущение, сообразно которому добро представлялось мне красивым, а зло - безобразным. Впоследствии, став социал-демократом, я отошел от религии, но эстетический критерий в вопросах морали, привитый ею мне в детстве, остался у меня на всю жизнь» [I, с. 446-447].

С другой стороны, на мировоззрение Вановского огромное влияние оказало радикальное окружение с его рабочими кружками и их серьезной образовательной программой, включающей обязательное изучение первоисточников. Вановский, спустя многие десятилетия, вспоминал: «В результате, была принята программа, состоявшая из следующих пунктов: I) Происхождение мира по Канту и Лапласу, 2) происхождение человека по Дарвину, 3) история первобытной культуры по Тэйлору, 4) происхождение семьи и государства по Энгельсу. И, в заключение - материалистическое понимание истории по Марксу» [г, с. 450].

С третьей стороны, огромное, возможно, даже решающее влияние оказывали старший брат и книги, которые тоже формировали мировоззрение, эстетический вкус и характер: «Я брал книги по его (брата Виктоpa. - A.Н.) совету, но далеко не всё было мне доступно. Так Златовратского и Глеба Успенского я бросил с первых страниц, но Писарев привел меня в восторг. Особенно мне нравился его критический выпад против Пушкина, в котором он разгромил всё великолепное здание его творчества. Это критическое варварство, к сожалению, надолго отвлекло меня от великого поэта. Читал я и Чернышевского “Что делать?”. Но социалистические фаланстеры, что снились героине его романа, меня не пленили. Я любил родных, и жизнь в семье казалась мне гораздо интересней и приятней жизни среди чужих людей, хотя бы и в хрустальном дворце. К Рахметову, являвшему собой тип революционера-аскета и подвижника, я относился с большим уважением, но Инсаров Тургенева, боровшийся за свою Родину, был мне и ближе, и понятней. В эпоху стачечной революции г905 года все революционеры походили на Рахметова, хотя и не спали на гвоздях, как герой Чернышевского, старавшийся закалить себя на случай пытки. Психологический парадокс заключался в том, что жертвенный идеализм, составлявший основу их мироощущения, резко противоречил материалистической философии, какую они исповедовали. Но тогда никто не придавал значения подобному противоречию, таившему в себе, к слову сказать, зерно религиозного социализма» [I, с. 45I-452]. 
Фольклор и мифология каждого народа - это сложное историко-мировоззренческое образование, и задача фольклориста-этнографа в XIX в. заключалась в выделении исторических пластов и их анализе. Недаром фольклористику и этнологию часто при этом прямолинейно сравнивали с геологией. Но если геология способна рассказать об истории формирования земной поверхности, то этнология раскрывает историю «умственного развития человечества». Вся история человечества - это цепь бесконечных этнических перемещений и взаимовлияний. Одни этносы завоевывали другие, вступали в тесные контакты, что сказывалось на их образе жизни, на их мышлении, на системе религиозных представлений. Иногда такое влияние значительно (например, Египта на Грецию), а иногда и огромно (например, Греции на Рим).

Древнейший памятник древне-японской литературы «Ко́дзики» («Записи о деяниях древности») был одним из первых письменных памятников Японии и являлся главной священной книгой синтоистского Троекнижия. Этот сложный в жанровом отношении литературный памятник представлял собой Свод древних легенд, мифов, исторических песен и хроник. В Предисловии к «Кодзики» утверждалось, что сказитель Хиэда-но Арэ спел эти священные тексты, а ученый придворный, которого звали O-но Ясумаро, записал и истолковал весь огромный мифологический массив, а также сохранившийся героический эпос японского народа. Через все тексты «Кодзики» проходила главная идея этого памятника: утвердить божественное происхождение императорского дома и его незыблемое постоянство. Учитывать все эти обстоятельства, в том числе и обстоятельства явно политического свойства, русскому эмигранту было жизненно необходимо.

Вановский считал, что любая наука, в том числе и общественная, не может строиться лишь на догадках; ей нужен строгий научный аппарат, своего рода универсальный метод, который раскрывал бы и объяснял «белые пятна» в истории развития человечества. Именно такой универсальный метод и пытался создать Вановский, анализируя японские «мифы мироздания» (в настоящее время подобные мифы называют «архаическими мифами творения» [5, с. 194]).

В первом из трех свитков «Кодзики» содержались сами архаические мифы творения - от космогонических мифов о сотворении Вселенной до мифов о богах-прародителях, о сотворении Земли, о героических подвигах 
божественных предков и героев и, наконец, о появлении на Свет Отца легендарного вождя страны Ямато Иварэ-хико, который и стал первым императором Японии. С тех легендарных времен императорский род никогда не прерывался, и этот императорский род будет править Японией вечно.

«Кодзики» был весь пронизан синтоистской идеей божественного происхождения японского императора, и этот постулат разделяло все японское общество. Никоим образом не допускались никакие сомнения и тем более намеки на иное толкование этой идеи. Желание Вановского обрести, наконец, идеологическую свободу в очередной раз окончилось неудачей. Уже не в Советской России, а в императорской Японии он столкнулся с жесткими идеологическими тисками, обусловленными не примитивными классовыми интересами, а синтоистской религией и мощным пластом древнего мифологического мышления японского народа.

Мифологическая картина мира, предложенная «Кодзики», до определенного момента напоминала Вановскому традиционную общеевропейскую мифологическую схему, знакомую ему еще по гимназическому курсу. Типологическое сходство между, например, древнегреческой мифологической системой и древнеяпонской было очевидно - скажем, схожая схема мифологического мироздания. Она представлена в мифах о том, как из левого глаза Бога-прародителя Идзанаги появилась богиня Аматэрасу, олицетворявшая собой Солнце; как из правого глаза появился бог Цукиюми, олицетворявший собой Луну; как из носа появился бог Сусаноо, олицетворявший собой бури и штормы, а сам бог Сусаноо стал повелителем Моря. Впоследствии Бог-прародитель Идзанаги разделил Мир между своими детьми: Аматэрасу становится главным божеством японского мифологического Пантеона, получает во владение Высокое Небо и становится покровительницей земледелия.

Важную роль в японских архаических мифах творения играла богиня Идзанами (Богиня, влекущая к себе) - сестра и она же жена бога Идзанаги (Бог, влекущий к себе). Брат и сестра Идзанаги и Идзанами находились в кровосмесительной связи. Это были «первые люди и первые синтоистские боги. Брат и сестра, муж и жена. Породили все живое и существующее. Аматэрасу, Сусаноо и Цукиюми - дети, порожденные из головы бога Идзанаги после ухода богини Идзанами в Страну Мрака» [II, C. 42I]. 
Традиционная исследовательская схема, предложенная А.А. Вановским и М.П. Григорьевым - на тот момент лучшим знатоком японского языка среди русских, проживавших тогда в Японии, - полностью устраивала и Вановского. Однако эта схема никак не могла объяснить миф о богине Идзанами и боге Сусаноо. И.П. Кожевникова приводит слова самого Вановского, который утверждал, что «наибольшую трудность для толкования мифа представляет собой история злосчастной богини Идзанами. Богиня-прародительница, спустившаяся с небес вместе с богом Идзанаги и сочетавшаяся с ним браком, родила восемь Великих японских островов, множество мелких, реки, горы и всё растущее на них, и богов, ведающих всем этим. Последним она родила бога огня, ставшего причиной ее смерти. Неутешный вдовец бог Идзанаги решил отправиться за возлюбленной супругой в страну теней, чтобы уговорить ее вернуться. Но, увидев, что тело богини уже кишело червями и истекало гноем, он пустился наутек и закрыл выход из страны теней огромной скалой. И разгороженные ею боги-супруги расторгают свой брачный союз, становясь непримиримыми врагами» [4, с. I56].

Решение загадки этого «странного» японского мифа Вановскому подсказало то давнее сибирское «космическое видение», которое не только привело его в Японию, но и вручило ему, как оказалось, ключ к разгадке тайны японской мифологии. Ключом к пониманию «Кодзики» является именно вулканическая природа Японии. Вановский считал, что «стоит только поставить вопрос, как сам собой напрашивается ответ: вулканы, рождающие из своего чрева целые острова, извергающие пламя и затем переходящие в состояние покоя, иначе говоря, превращающиеся в мертвые вулканы, есть та космическая почва, на которой возник миф о богине Идзанами. Богиня Идзанами - богиня земли, но не только в смысле богини плодородия, но и в смысле богини вулканической стихии, породившей японские острова. Эта вулканическая природа богини Идзанами является самой главной чертой ее характера и она-то и мешает уложить японский миф о творении в схему греческого и вавилонского мифов» [4, с. 157].

Еще один «темный», по мнению Вановского, эпизод «Кодзики» тоже был связан с темой вулканической деятельности. Изучая историю японских вулканов, Вановский явил собой новый тип исследователя, объединившего в себе талант фольклориста-этнолога и талант естествоиспытателя, что явилось уникальным событием в мировой науке, как естественной, так и 
гуманитарной. Именно это уникальное сочетание двух, казалось бы, несовместимых исследовательских векторов позволило Вановскому прийти к выводу, что извержение вулкана имеет не только пагубные, но и добрые, положительные последствия. Например, вулканическая грязь оказывается плодородной почвой для различных культурных растений, скажем, для винограда. Поэтому и богу вулканов Сусаноо приписываются разные добрые дела. Сусаноо как вулканический бог вообще предстает одним из самых ярких и любимых японских богов.

Вановский приходит к выводу, что плач и бунт Сусаноо олицетворяют собой картину грандиозного извержения огромного вулкана. Кроме того, он полагает, что геология могла бы помочь в определении времени возникновения мифа, учитывая данные об извержении того или иного вулкана в древности. Вановский считает: первоначально древний человек видел в богах Идзанами и Сусаноо богов вулканической стихии, что было в последующие века забыто. Вулканические боги из-за своего буйного и неуравновешенного характера были не способны творить и поддерживать порядок на Земле. Богиня Аматэрасу послала на Землю своих потомков, понимая, что только небесные боги могут принести с собой порядок и устроить государство. Сам Вановский выразил эту синтоистскую идею еще красочнее, совсем в духе классической японской поэзии: «Богиня Аматэрасу создает государство, посылая на землю свою душу, заключенную в зеркало» [2, с. 42].

«Это прекрасная страна, - передает Кожевникова слова Вановского, - страна его “космического сновидения” поистине была отмечена перстом судьбы. Она стояла на зыбкой, постоянно колеблющейся земле и так близко соприкасалась с раскаленной магмой, что в ней постоянно ощущалось пульсирование чрева планеты. С первых дней приезда в Японию, продолжает Кожевникова, - Ванновский постоянно ощущал его в землетрясениях, которые вызывали в нем двойственное чувство: “немного жутко, но интересно”. Он начинает интересоваться происхождением японских островов, катаклизмами, которыми так богата японская природа. Вулканы с их грозной силой захватили Вановского» [4, с. 154].

Он пешком совершает подъем на вершину потухшего вулкана Фудзи, самой высокой и почитаемой горы Японии. Пишет поэтическое эссе «Японский богатырь», в котором сравнивает Фудзи-сан с воином, стоящим на страже «счастья и покоя японского народа». 
В 2о0г г. в майском выпуске журнала «Восточная коллекция» Т.В. Померанская и автор настоящего исследования опубликовали статью «Путь и судьба Александра Вановского», где среди прочих уникальных материалов была опубликована фотография Вановского верхом на коне в белом тропическом шлеме во время его очередной «фольклорно-вулканологической экспедиции». Вановский выступал во время нее в двойной ипостаси - естествоиспытатель, изучающий вулканическую деятельность как уникальное явление японской Природы, и фольклорист-этнолог, изучающий «вулканологические мифы» древней Японии». Под фотографией есть приписка самого Вановского: «1959 год. Это меня сняли во время подъема на вулкан Михара-Яма, который находится на острове Ошима» [6, с. І29].

Вулканы, а говоря более определенно, «вулканология» и даже «геология», наряду с изучением японской мифологии, становятся важными частями его исследовательской деятельности. Кожевникова отмечает, что «вулканы, которые, по мнению многих авторитетов, во многом определили быт японцев и выковали их характер, стали для Вановского той точкой отсчета, от которой начались его основные гипотезы, легшие в основу его работ» [4, с. I54].

Решающее значение для Вановского имели сотрудничество и дружба с Михаилом Петровичем Григорьевым. Овладение уникальной японской культурой Вановский начал с изучения такого специфического жанра японской литературы, как «кайдан» - рассказы о привидениях. Особенно его интересовала тема загробной мести, встречающаяся как в русской, так и в европейской литературе. Выполненные переводы текстов не устраивали Вановского, и именно тогда он обратился к лучшему на тот период времени переводчику с японского языка, Михаилу Петровичу Григорьеву (І899-І943), бывшему офицеру войск атамана Г.М. Семенова, служившему в годы Гражданской войны переводчиком в штабе японских оккупационных войск в России.

Не только исследования Вановского стали итогом их совместной деятельности над текстами «Кодзики», но и труд самого Григорьева «Древнейший памятник японской литературы Кодзики», опубликованный в первом выпуске издававшегося в Токио под редакцией самого М.П. Григорьева сборника «На Востоке». Некоторое представление об уникальности этого издания может дать приводимый ниже краткий обзор опубликованных в нем материалов. Среди участников первого выпуска были указаны следу- 
ющие авторы: Александр Вановский, писатель, автор книг о японской мифологии; Георгий Иванович Чертков (г893-1983), член Сибирского правительства во главе с А.В. Сазоновым, писатель, который жил в Японии, Китае, США; Николай Матвеев (I866-I94I), писавший под псевдонимом Амурский, прозаик и поэт, живший в эмиграции в Японии; Павел Петрович Петров (1882-1967), генерал-лейтенант, начальник отдела РОВС в Мукдене, председатель Общества русских эмигрантов в Японии.

Сборник «На Востоке» давно стал библиографической редкостью. В настоящее время известно лишь о четырех экземплярах сборника, хранящихся в крупнейших библиотеках мира: один - в Баварии (Германия), один - в библиотеке Гарвардского университета (США), один - в библиотеке Токийского университета (Япония) и один - в библиотеке Гавайского университета (США).

Являясь редактором сборника «На Востоке», Григорьев публиковал собственные материалы под скромным псевдонимом «М.Г.». По этой причине многие его работы, среди которых оказалось и исследование «Древнейший памятник японской литературы Кодзики», затерялись среди маститых и громких имен других исследователей, как русских, так и японских. Содержание первого выпуска сборника действительно производило сильное впечатление. Вановский опубликовал новеллу «Японский богатырь» и статью «Зеркало судьбы (Сон Татьяны)». Григорьев (под псевдонимом «М.Г.») - статьи «Древнейший памятник японской литературы Кодзики» [3], «Несколько слов о старой и новой поэзии Японии», «Новые поэты Японии», «Лик Японии», «Танизаки Дзюнъичиро (краткая характеристика писателя)», «Акутагава Рюносукэ (краткая характеристика писателя)». Кроме работ русских авторов, в сборнике были напечатаны переводы произведений Акутагавы Рюносукэ, Исигава Такубоку и других японских писателей.

Кожевникова подробно рассказывает о начале совместной работы Вановского и Григорьева над текстами «Кодзики»: «Вановский познакомился с Григорьевым в конце 2о-х годов. Зная о его загруженности, он не очень надеялся склонить его заниматься изысканиями в древней литературе. Но к удивлению Александра Алексеевича тот охотно согласился. Когда Вановский заикнулся о вознаграждении за эту работу, он замахал руками и отказался: Меня интересует сам предмет, а не деньги, да и откуда они у вас! Оказалось, что в это время Григорьев сам мечтал, кроме практических пере- 
водов, необходимых для заработка, начать заниматься японской литературой, мечтая в будущем написать историю Японии, иллюстрировав каждый ее этап художественными произведениями той эпохи. Вскоре они перешли к началу начал японской литературы - к “Кодзики”» [4, с. I55].

О ходе совместной работы Вановский рассказывал следующее: «Сидим за “Кодзики”. Он переводит с листа, поясняя текст комментариями профессора Цугита. Со свойственной ему деловитостью он запасся необходимыми пособиями и, прежде всего, двумя увесистыми томами примечаний и пояснений к мифологическому периоду японской истории этого профессоpa. <..> Я обращаю его внимание на эпизоды, что могут понадобиться мне для статьи, и он дает мне их точный перевод». Наверное, только специалист может оценить познания и эрудицию тогда еще совсем молодого Григорьева - ему было около тридцати или тридцать с небольшим. К тому же он не был специалистом по древней литературе, не имел ни университетского образования, ни филологической подготовки. В чем же была главная трудность? Вановский объясняет ее так: «Мы ищем в “Кодзики” объединяющего начала, которое позволило бы нам понять японский миф как одно художественное целое. Нам нужна теория, исходя из которой можно было бы объяснить все темные и загадочные места мифа. А их так же много, как и в Гамлете. В поисках ключа обращаемся к обширной литературе о “Кодзики”. Но она нас не удовлетворяет, ибо в ней, как и в литературе о Гамлете, имеется несколько глубоких и оригинальных воззрений, а всё остальное сплошь вариации к ним. И мы ходим к специалистам по “Кодзики”, которые любезно принимают нас и дают указания, которые все-таки не выводят нас из лабиринта мифа». Дело заключалось в том, что Вановский и Григорьев рассматривали сюжет «Кодзики» как борьбу двух начал - начала светлого, организующего и темного, хаотического. Но в эту схему никак не укладывались богиня Идзанами и бог Сусаноо. В конце концов, пришлось признать подобную попытку неудавшейся. Но хоть загадка мифа и не была решена, совместный многолетний труд принес плоды. Оба досконально изучили «Кодзики» [4, с. I55-I56].

Однако проблема неразгаданного мифа о «странном» поведении некоторых японских богов продолжала оставаться центральной темой кропотливых исследований Вановского. Он внезапно, как иностранец, обратил внимание на то, что для японцев вулканическая активность является «обыч- 
ным делом», и в силу этого им просто не приходило в голову исследовать японские эпические памятники с точки зрения геологии и вулканологии.

Выводы Вановского и Григорьева о вулканической природе древних японских мифов творения были представлены японской научной общественности достойно: с русским размахом и японской деликатностью одновременно: «Весьма вероятно, - писал Вановский, - что древний человек видел в богах Идзанами и Сусаноо богов вулканической стихии. Но прошли века и первоначальный подлинный характер названных богов был забыт» [4, с. I58-I59]. Вановский, в развитие своей теории, приходил к выводу, «что в силу буйного и беспорядочного характера вулканических богов они не могут творить и не могут создать на земле порядок» [4, с. I59]. Именно поэтому «богиня Аматэрасу послала на землю своих потомков, потому что только они, небесные боги, могут принести с собой порядок и устроить государство» [4, с. I59], полемизируя тем самым с японскими учеными, которые считали, что «Кодзики» является всего лишь бессистемным собранием разных легенд, лишенным внутренней связи, лишенным единой повествовательной линии. Причину этого Вановский объяснял тем, что со временем была забыта «вулканическая подкладка» мифа, которая придавала внутреннюю связь излагаемым в мифе событиям.

В г960 г. в Токио на японском языке выходит его книга «Вулканы и Солнце: Новая концепция мифологии “Кодзики”». В заключительной главе, озаглавленной «Миф о творении в “Кодзики” и Библии» и являвшейся переработанным вариантом его знаменитой статьи, опубликованной в I934 г. в парижском журнале «Путь», Вановский сравнивает сакральные тексты обоих памятников и выделяет общее и особенное в этих памятниках. Он отмечает совпадение методов творения в обоих сакральных памятниках.

Если в тексте Библии Бог творит посредством Слова, то в тексте «Кодзики» Бог Амэ-но-Минака-нуси, что значит Властитель Небесного Царства творит Мир посредством своей творческой энергии через других богов (сущностей), чьи имена указывают на порядок и предмет творения. «Выходит, - считает автор, - что японские боги - это те же библейские слова, с помощью которых творился миф, только персонифицированные и обожествленные. Такое сходство наталкивает на мысль, что оба мифа вышли из какого-то одного источника, которым Вановский вслед за некоторыми японскими учеными считает мифы древней Месопотамии» [4, с. I59]. 
Гипотеза о том, что предки японского народа вышли из Месопотамии, была достаточно популярна в зо-е гг. XX столетия. Например, один из авторов сборника «На Востоке», где активно печатались и Григорьев, и Вановский, писатель Оябэ Дзэнитиро даже выдвинул смелое «предположение, что «предками японского народа были евреи, пришедшие из Малой Азии. Исследователь “Кодзики” Исикава Сансиро тоже считал, что предки японцев вышли из Месопотамии, но он считает ими древнее племя, жившее в верховьях реки Евфрат, которые по пути смешались с другими народами - семитами, малайцами и полинезийцами. Вановский приводит утверждение Исикава, что Страна пышного тростника, в которой небесные боги наводят порядок, находится именно в Месопотамии, а не в Японии, где нет обширных болот, поросших тростником. Исикава также считал, что название страны богов Такамагахара идет от названия города Харон, родины иудейского патриарха Авраама» [4, с. I59]. Как мы видим, вокруг проблемы этногенеза японского народа в зо-е гг. XX столетия кипели нешуточные фольклористические и этнологические страсти.

Исследования японских ученых, по мнению Вановского, подтверждали его выводы о сходстве архаических мифов творения в двух великих памятниках мировой культуры - в Библии и в «Кодзики». «Но, - задает он вопрос, - если предки японского народа принесли с собой с азиатского материка миф о происхождении земли, то, спрашивается, зачем им понадобилось создавать еще дополнительный миф о рождении японских островов?» [4, с. I59]. Он выдвинул оригинальную гипотезу, суть которой заключалась в следующем: «Предки японцев, двигающиеся с азиатского материка на Восток, должны были прежде всего попасть на богатый вулканами остров Кюсю. Там, кроме находящегося на побережье вулкана Сакурадзима, имеется еще гигантский вулкан Асо, “настоящее царство вулканов” [4, с. I59]. Он отправляется в научную экспедицию, которую сегодня можно назвать «комплексной», чтобы понять то грандиозное действо, которое неоднократно происходило в геологической истории Японии. Он пытался уловить настроение возникновения мифа, писал о поисках этого мифологического настроения, о поэзии рождения японского вулканического мифа буквально следующее: «Помимо самого Асо, обладающего пятью огромными кратерами, имеется еще обширное кратерное поле, а также целый ряд отдельных вулканов, вытянувшихся в струнку, подобно солдатам, построенным 
в одну шеренгу. Трудно себе даже представить, что произойдет, если такая вулканическая махина “заплачет” и “забунтует” всеми своими кратерами!» [4, с. I6o].

Вановский считал, что древние переселенцы явились свидетелями такого сильного извержения. «В каком бы направлении пришельцы ни передвигались по острову, они непременно должны были натолкнуться на Асо, ибо он находится в самом его центре, близ современного города Кумамото. Вспомним еще, что на азиатском материке, откуда они пришли, за исключением отдаленной Камчатки, нет действующих вулканов. Перевоплотимся в душу древнего человека, впервые узревшего грандиозные проявления вулканической деятельности, и мы поймем, что он должен был пережить сильнейшую потребность уяснить себе их значение. И вот тут на помощь ему приходит дар мифотворчества, ибо назначение мифа в том и заключается, чтобы путем одушевления природы служить осознанию ее явлений. Так и возник миф о богине Идзанами, рождающей острова, подобно тому, как вулканы извергают из своего чрева новые образования земли». Знакомство с деятельностью вулкана Асо подтвердили предположения Вановского о буйном боге вулканов Сусаноо. В окрестностях вулкана есть небольшое озеро, которое временами совершенно высыхает, точно его «выплакал» $C y$ саноо. Огромные массы пепла издали похожи на проливной дождь, от которого могло пойти представление о «слезах вулкана», а зрелище извержения, когда небо застилается тучами черного дыма, закрывающего солнце, - о борьбе вулканического бога с солнцем. Так постепенно мог сложиться миф о плаче и бунте Сусаноо [4, с. І6о].

Вановский делает свой вывод о сути вулканической основы архаических мифов творения Древней Японии: «Вулканические впечатления, вот фактор, сыгравший огромную роль в развитии мифотворчества. Вулкан Асо, можно сказать, - колыбель мифологии “Кодзики” - этого родного детища японской земли» [4, с. I60].

Работа Вановского «Вулканы и Солнце», где были сформулированы основные положения его «вулканической теории» происхождения архаических мифов творения Древней Японии, не стала предметом обсуждения японских мифологов. Началась война, и «автор, как и многие другие иностранцы, был интернирован в горное место Каруидзава, а потом послевоенная разруха <...> не способствовали ее публикации» [4, с. I6о]. 
Следует согласиться с И.П. Кожевниковой, когда она с горечью говорит о забвении в современной Японии «мифолого-вулканологических» трудов нашего гениального соотечественника. Однако если вспомнить, как и когда в головах двух русских эмигрантов, Александра Вановского и Михаила Григорьева, в муках и сомнениях возникла совершенно фантастическая теория «вулканического происхождения архаических мифов творения Древней Японии», то становится совершенно очевидно, что исторический контекст, вместивший в себя и Первый съезд РСДРП, и две русские революции, и две мировых войны, и Гражданскую войну с ее белым и красным террором, и горький хлеб эмиграции с ее унижениями и борьбой за «место под солнцем», и многое другое, - именно этот исторический контекст и сформировал для японской фольклористики русскую концепцию. Отрадно, что многие в Японии понимают и ценят этот научный факт, чему свидетельством может послужить следующая благодарственная цитата: «По свидетельству влиятельной синтоистской газеты “Священный путь” от г апреля І96г года “С первой страницы до последней книга А.А. Вановского полна серьезным научным материалом, но, благодаря мастерскому изложению писателя, она легко читается. "Вулканы и Солнце” содержит совершенно новый взгляд на “Кодзики”. До сих пор я ни в одной книге не читал и не слышал такого толкования. По прочтении “Вулканы и Солнце” передо мной впервые открылся мир наших мифов. И особенно замечательно, что эта ясная картина дана иностранным ученым, а не японским” $[8$, с. 23].

Полностью исчерпав для себя исследовательскую тему, связанную с архаическими мифами творения Древней Японии, Вановский сосредоточил свое внимание на «шекспировской теме», в чем добился ощутимых результатов, создав книгу «Путь Иисуса от иудаизма к христианству (обнаружение скрытого иудейского сюжета в трагедии “Гамлет”)», в которой за образом Гамлета Вановскому видится образ Христа. Таким образом, великая трагедия Шекспира обретает для него свой истинный потаенный смысл. 


\section{Список литературы}

I Вановский А.A. «Бурные годы» Александра Вановского // Российский Архив. М.: Российский фонд культуры, 20I7. Вып. 23: История Отечества в свидетельствах и документах XVIII-XX вв. С. 440-468.

2 Вановский А.А. Миф о творении в Кодзики и Библии. Отрывки из книги «Вулканы и Солнце» // Яковенко М.М. Мечтатель. Повесть о А.А. Вановском. М.: [Б.и.], г999. С. 37-47.

3 Григорьев М.П. Древнейший памятник японской литературы «Кодзики» // На Востоке. Токио: Изд-во книжного магазина Тайсиудоо, г935. Вып. І. 228 с.

4 Кожевникова И.П. Вановский и Япония // Acta Slavica Iaponica. I995. Vol. I3. С. I49-I66.

5 Мелетинский Е.М. Поэтика мифа. М.: Наука, 1976. 407 с.

6 Налепин А.Л., Померанская Т.В. Путь и судьба Александра Вановского // Восточная коллекция. 200I. № 2. С. І29-І33.

7 Налепин А.Л. Японский фольклор в работах А.А. Вановского и их значение для русско-японского культурного трансфера // Studia Litterarum. 20I8. T. 3, № 4 . С. 276-297.

8 Палиевский П.В. Пушкинское эхо из Японии // Родная Кубань. 1999. С. 77-80.

9 Яковенко М.М. Мечтатель. Повесть о А.А. Вановском. М. [Б.и.], І999. С. І-47.

го Яковенко M.M. «Куда ушла моя жизнь?..» Повествование в письмах, дневниковых записях, воспоминаниях и официальных документах о жизни и трудах Александра Алексеевича Вановского. М.: Звенья, 2009. 296 с.

II Японская мифология. Энциклопедия. М.: Эксмо, 2007. 464 c.

I2 Fewkes J.W. Tussayan Migration Traditions // Nineteenth Annual Report of the Bureau of American Ethnology. Washington, I900. Part 2. P. 573-633.

I3 McNeil W.K. History in American Folklore: An Historical Perspective // Western Folklore. 1982. Vol. XLI, № I. P. 30-35. 


\section{References}

I Vanovsky A.A. "Burnye gody" Aleksandra Vanovskogo ["Stormy Years” by Alexander Vanovsky]. In: Rossiiskii Arkhiv [Russian archive]. Moscow, Rossiiskii fond kul'tury Publ., 20I7, issue 23: Istoriia Otechestva v svidetel'stvakh i dokumentakh XVIII-XX vv. [History of the Fatherland in the testimonies and documents of the $18^{\text {th }}-2 \mathrm{O}^{\text {th }}$ centuries], pp. 440-468. (In Russ.)

2 Vanovsky A.A. Mif o tvorenii v Kodziki i Biblii. Otryvki iz knigi "Vulkany i Solnce” [The creation myth in the Kojiki and the Bible. Excerpts from the book Volcanoes and the Sun]. In: Yakovenko M.M. Mechtatel'. Povest'o A.A. Vanovskom [A Dreamer. The story of Alexander A. Vanovsky]. Moscow, I999, pp. 37-47. (In Russ.)

3 Grigor'ev M.P. Drevneishii pamiatnik iaponskoi literatury "Kodziki” [The oldest work in Japanese literature, “Kojiki”]. In: Na Vostoke. Vypusk pervyi [In the East]. Tokio, Izdatel'stvo knizhnogo magazina Taisiudoo Publ., I935. Issue I. 228 p. (In Russ.) Kozhevnikova I.P. Vanovskii i Iaponiia [Vanovsky and Japan]. Acta Slavica Iaponica, I995, vol. I3, pp. I49-I66. (In Russ.)

Meletinskii E.M. Poetika mifa [The poetics of the myth]. Moscow, Nauka Publ., I976. 407 p. (In Russ.)

Nalepin A.L., Pomeranskaia T.V. Put' i sud'ba Aleksandra Vanovskogo [Life and career of Alexander Vanovsky]. Vostochnaia kollektsiia, 200I, no 2, pp. I29-I33. (In Russ.) Nalepin A.L. Iaponskii fol'klor v rabotakh A.A. Vanovskogo i ikh znachenie dlia russkoiaponskogo kul'turnogo transfera [Japanese folklore in the works of A.A. Vanovsky and their significance for the Russian-Japanese cultural transfer]. Studia Litterarum, 20I8, vol. 3, no 4, pp. 276-297. (In Russ.)

Palievskii P.V. Pushkinskoe ekho iz Iaponii [Pushkin's echo from Japan]. In: Rodnaia Kuban' [Native Kuban'], I999, pp. 77-80. (In Russ.) Iakovenko M.M. Mechtatel'. Povest'o A.A. Vanovskom [Dreamer. Tale of A.A. Vanovsky]. Moscow, I999, pp. I-47. (In Russ.) Iakovenko M.M. “Kuda ushla moia zhizn'?..” Povestvovanie v pis'makh, dnevnikovykh zapisiakh, vospominaniiakh i ofitsial'nykh dokumentakh o zhizni i trudakh Aleksandra Alekseevicha Vanovskogo [“Where has my life gone?..” Letters, diaries, memoirs, and official documents on the life and works of Alexander Alekseevich Vanovsky]. Moscow, Zven'ia Publ., 2009. 296 p. (In Russ.) Iaponskaia mifologiia. Entsiklopediia [Japanese mythology. Encyclopedia]. Moscow, Eksmo Publ., 2007. 464 p. (In Russ.) Fewkes J.W. Tussayan Migration Traditions. Nineteenth Annual Report of the Bureau of American Ethnology. Washington, I900, part 2, pp. 573-633. (In English) McNeil W.K. History in American Folklore: An Historical Perspective. Western Folklore, I982, vol. XLI, no I, pp. 30-35. (In English) 